\title{
Edukasi Perilaku Hidup Bersih Sehat dan Pembagian Masker, Handsanitizer kepada Warga Jatisari
}

Education on Healthy Lifestyle, Distribution of Masks, and Hand-sanitizers to Communities

\author{
Fitria Nugrahaeni*1 ${ }^{*}$ Etin Diah Permanasari ${ }^{2}$ \\ 1,2 Jurusan Farmasi, Fakultas Farmasi Universitas Muhammadiyah Prof.DR.HAMKA, Jakarta \\ e-mail: *17itria.nugrahaeni@uhamka.ac.id, ${ }^{2}$ etindyah@yahoo.com
}

\begin{abstract}
Abstrak
Perilaku Hidup bersih dan sehat (PHBS) merupakan langkah yang harus diaplikasikan untuk mencapai derajat kesehatan yang baik bagi setiap orang. Masyarakat di RT 01 RW 02 Jatisari Bekasi merupakan tempat yang masyarakatnya masih kurang pengetahuan dan informasi sehingga masalah kesehatan masyarakat masih menjadi masalah yang cukup besar. Selain itu akhir-akhir ini sedang terjadi pandemi virus korona yang berbahaya bagi tubuh. Sehingga sangat dibutuhkan edukasi mengenai PHBS dan pencegahan penyakit korona serta penyakit lainnya salah satunya dengan menggunakan masker dan rajin cuci tangan dan kalau di luar jangan lupa menggunakan handsanitizer. Pengabdian ini bertujuan untuk meningkatkan pengetahuan, kesadaran, kemauan dan kemampuan masyarakat untuk melakukan PHBS dalam meningkatkan mutu hidup serta meningkatkan taraf kesehatan masyarakat. Metode yang digunakan adalah memberikan kuesioner dan penyuluhan. Kuesioner diberikan 1 hari sebelum pelaksanaan kegiatan dan setelah pelaksanaan kegiatan kepada 55 responden dengan tetap jaga jarak. Hasil kuesioner digunakan untuk mengetahui pemahaman masyarakat tentang PHBS dan sebagai indikator keberhasilan dari kegiatan. Penyuluhan disampaikan dengan tema PHBS, cara cuci tangan yang benar, dan cara memakai masker yang benar. Selain itu dilakukan pembagian masker dan handsanitizer kepada warga. Hasil penyuluhan menunjukkan terdapat peningkatan yang signifikan pemahaman masyarakat tentang masalah tersebut dari 18,18\% menjadi 98,18\%. Berdasarkan hasil ini diharapkan masyarakat dapat menerapkan pengetahuan tersebut dengan benar demi mewujudkan derajat kesehatan masyarakat yang setinggi-tingginya.
\end{abstract}

Kata kunci — perilaku hidup bersih dan sehat, penggunaan masker, cuci tangan, pengabdian masyarakat

\footnotetext{
Abstract

A clean and healthy lifestyle (PHBS) is a step that must be done to achieve optimal health status for everyone. The community in neighborhood (RT 01) hamlet (RW 02) of Jatisari Bekasi is an area where people still lack knowledge and information, so that public health problems are still quite a problem. Besides, there is currently a pandemic of COVID-19, which is harmful to the body. Education about PHBS and prevention of corona disease and other diseases is very much needed, one of which is using a mask and washing your hands diligently. If outdoors, don't forget to use hand sanitizer. This service aimed to increase the knowledge, awareness, willingness, and ability of the community to carry out PHBS to improve the quality of life and improve public health standards. The method used is to provide questionnaires and counseling. The questionnaire was given one day before the implementation of the activity and after implementing the activity to 55 respondents while maintaining a distance. The questionnaire results were used to determine the community's understanding of PHBS and as an
} 
indicator of the success of the activities. The counseling was delivered on the theme of PHBS, how to wash hands properly, and how to wear masks correctly. Also, masks and hand sanitizers were distributed to communities. The counseling results showed an significant increase in public understanding of the problem, from $18.18 \%$ to $98.18 \%$. Based on these results, it is hoped that the community can apply this knowledge correctly to realize the highest public health status.

Keywords — clean and healthy lifestyle, mask, hand-sanitizer, community services

\section{PENDAHULUAN}

Perilaku Hidup bersih dan sehat (PHBS) merupakan langkah yang perlu diaplikasikan untuk mencapai derajat kesehatan yang baik bagi setiap orang. Kondisi sehat harus diupayakan secara berkesinambungan dari yang tidak sehat menjadi hidup yang sehat selain itu juga menciptakan lingkungan tempat tinggal yang sehat. Upaya ini harus dimulai dari menanamkan pola pikir sehat kepada masyarakat yang harus dimulai dan diusahakan oleh diri sendiri [1] [2]. Upaya dilakukan mewujudkan derajat kesehatan masyarakat setinggi-tingginya sebagai satu investasi bagi pembangunan sumber daya manusia yang produktif [3]. Dalam sebuah keluarga, anggota keluarga mempunyai daya tahan tubuh berbeda-beda pada musim tertentu, ketika daya tahan tubuh menurun maka virus, bakteri mudah masuk ke dalam tubuh dan menyebabkan penyakit, oleh karena itu perlu sikap dari masyarakat untuk mengaplikasikan cara hidup sehat. Dalam mewujudkan perilaku ini perlu komitmen bersama-sama saling mendukung dalam meningkatkan derajat kesehatan masyarakat khususnya keluarga dalam lingkup terkecil sehingga pembangunan kesehatan nasional dapat tercapai maksimal.

Namun kenyataannya, di kawasan pedesaan perhatian masyarakat akan pentingnya melakukan PHBS masih minim, khususnya masyarakat di RT 01 Jatisari Bekasi, merupakan daerah dimana masyarakatnya masih kurang pengetahuan dan informasi sehingga masalah kesehatan masyarakat masih menjadi masalah yang cukup besar. Selain itu akhir-akhir sedang terjadi pandemi virus korona yang berbahaya bagi tubuh, penyebarannya selain lewat droplet juga dapat disebarkan lewat airbone [4]. Sehingga sangat dibutuhkan edukasi mengenai PHBS dan pencegahan penyakit korona serta penyakit lainnya salah satunya dengan menggunakan masker dan rajin cuci tangan dan kalau di luar jangan lupa menggunakan handsanitizer [5][6].

Solusi yang ditawarkan adalah melalui penjelasan tentang perilaku hidup bersih sehat, penggunaan masker yang benar sesuai standar WHO, pencegahan covid-19, cara cuci tangan yang benar dan penggunaan handsanitizer yang benar. Mencuci tangan dengan sabun atau menggunakan handsanitizer yang mengandung alkohol $70 \%$ bisa melemahkan bahkan membunuh virus dan bakteri yang terdapat pada tangan sehingga dapat mencegah penyebaran penyakit infeksi pernafasan, pencernaan dari satu orang ke orang yang lain [1] [7]. Pelatihan ini juga dilaksanakan supaya peserta dapat memahami PHBS dan menggunakan masker serta handsanitizer dengan benar. Diharapkan melalui program ini dapat meningkatkan pengetahuan, kesadaran, kemauan dan kemampuan masyarakat untuk melakukan PHBS dalam meningkatkan mutu hidup serta meningkatkan taraf kesehatan masyarakat demi mewujudkan kesehatan nasional setingi-tingginya.

\section{METODE PENELITIAN}

Pelaksanaan kegiatan ini di lingkungan RT 01 RW 02 Jatisari Jatiasih Bekasi pada 7 Agustus 2020 kepada 55 warga. Metode yang digunakan meliputi: 1) memberikan kuesioner (pretest) untuk mengetahui pengetahuan warga sebelum penyuluhan 1 hari sebelum pelaksanaan 
kegiatan, 2) memberi penyuluhan tentang perilaku hidup bersih dan sehat kepada warga secara door to door meliputi menggunakan air bersih untuk minum, mandi, mencuci piring dan pakaian, menggunakan jamban sehat, menghilangkan jentik di rumah masing-masing, makan sayur mayur dan buah-buahan setiap hari, melakukan aktivitas fisik setiap hari seperti jalan kaki 30 menit setiap hari, tidak merokok di dalam rumah, mencuci menggunakan air bersih dan sabun baik ketika masuk ke dalam rumah maupun sebelum makan, jika ada persalinan wajib diantarkan ke puskesmas atau rumah sakit agar dapat ditolong langsung oleh tenaga kesehatan yang berkompeten, karena sedang pandemi perlu penyuluhan tambahan penggunaan masker yang benar sesuai standar World Health Organization (WHO) seperti jika menggunakan masker kain maka gunakan masker yang 3 lapis, kemudian setelah dipakai sekali harus dicuci langsung, masker bedah dan masker N95 memang lebih efektif untuk menghalau masuknya bakteri dan virus ke dalam mulut dan saluran pernafasan, tetapi karena stoknya semakin menipis, masker bedah dan masker N95 lebih diutamakan untuk tenaga kesehatan yang bekerja di pelayanan kesehatan. 3) Setelah itu peserta pelatihan dan sosialisasi cara cuci tangan dan penggunaan handsanitizer yang benar sekaligus dilakukan pembagian masker dan handsanitizer 4) dilakukan posttest setelah mendapatkan materi tersebut untuk mengetahui pengetahuan mitra tentang PHBS, cara cuci tangan yang benar, penggunaan masker yang benar serta pendapat mitra tentang program ini bermanfaat atau tidak.

\section{HASIL DAN PEMBAHASAN}

Pengabdian masyarakat ini dibagi menjadi 4 tahap, yaitu pretest menggunakan kuesioner, penyuluhan dan pembagian masker, handsanitizer, pelatihan dan sosialisasi cara cuci tangan dan penggunaan handsanitizer, terakhir posttest menggunakan kuesioner. Pada tahap pretest didapatkan hasil pada tabel 1 dan tabel 2.

Setelah data diambil, sehari kemudian dilakukan penyuluhan dari rumah ke rumah dengan tetap menerapkan physical distancing dan protokol kesehatan mengenai perilaku hidup bersih dan sehat, penggunaan masker yang benar sesuai standar World Health Organization (WHO), serta pelatihan dan sosialisalsi cara cuci tangan dan penggunaan handsanitizer yang benar sekaligus dilakukan pembagian masker dan handsanitizer. Melalui penyuluhan ini diharapkan masyarakat mempunyai pengetahuan yang baik dalam menerapkan PHBS, dan penggunaan masker serta cuci tangan [9].

Sebelum dilakukan penyuluhan didapatkan data 32,7\% warga usia 40-49 tahun belum memiliki pemahaman mengenai PHBS, cara cuci tangan yang benar, menggunakan masker dan mencegah penyebaran covid (tabel 1). Berdasarkan hasil tersebut menggambarkan meskipun di media massa sudah mensosialisasi cara cuci tangan yang benar, pemakaian masker yang benar tetapi warga masih ada yang belum bisa memahami.

Tabel 1. Distribusi Pengetahuan Responden Sebelum Penyuluhan Berdasarkan Usia

\begin{tabular}{|c|c|c|c|}
\hline Pengetahuan & Usia & Frekuensi & Presentase (\%) \\
\hline \multirow{3}{*}{ Baik } & $20-29$ & 4 & 7,27 \\
\cline { 2 - 4 } & $30-39$ & 2 & 3,66 \\
\cline { 2 - 4 } & $39-49$ & 2 & 3,66 \\
\cline { 2 - 4 } & $>50$ & 2 & 3,66 \\
\hline \multirow{3}{*}{ Kurang } & $20-29$ & 10 & 18,18 \\
\cline { 2 - 4 } & $30-39$ & 13 & 23,6 \\
\cline { 2 - 4 } & $39-49$ & 18 & 32,7 \\
\cline { 2 - 4 } & $>50$ & 4 & 7,27 \\
\hline \multicolumn{2}{|c|}{ Jumlah } & 55 & 100 \\
\hline
\end{tabular}

Tabel 2. Distribusi Pengetahuan Responden Sebelum Penyuluhan 


\begin{tabular}{|c|c|c|}
\hline Pengetahuan & Frekuensi (F) & Presentase (\%) \\
\hline Baik & 10 & 18,18 \\
\hline Kurang & 45 & 81,82 \\
\hline Jumlah & 55 & 100 \\
\hline
\end{tabular}

Pada gambar 1 dapat terlihat penyuluhan dan pembagian masker dengan tetap melaksanakan protokol kesehatan disaat pandemi. Respon warga terhadap materi yang diberikan sangat baik dilihat dari antusias warga dalam menyimak materi yang diberikan dan memberikan timbal balik dengan mampu menjawab pertanyaan yang diberikan.

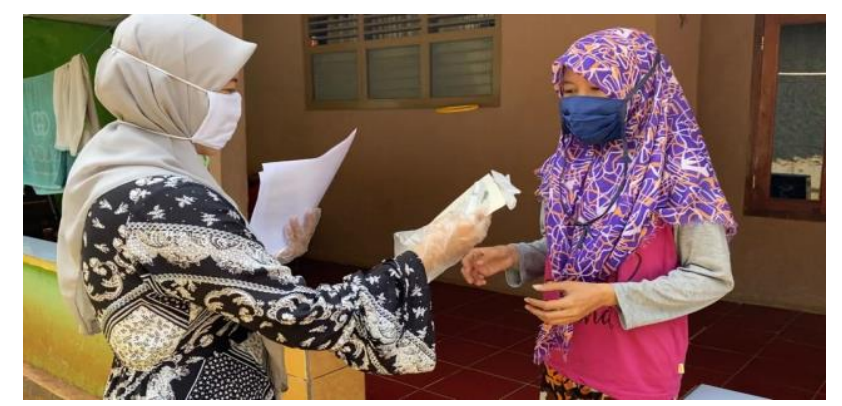

Gambar 1. Penyuluhan dan Pembagian Masker dan Handsanitizer

Pelatihan yang dilakukan seperti mencuci tangan dengan benar sesuai standar WHO yaitu 1)menuangkan cairan sabun atau antiseptik pada telapak tangan kemudian gosokkan pada kedua telapak tangan dengan arah memutar, 2) mengusap kedua punggung tangan secara bergantian, 3) membersihkan sela-sela jari tangan hingga bersih, 4)membersihkan ujung jari bergantian dengan saling mengunci, 5) menggosok dan memutar kedua ibu jari, 6) meletakkan ujung jari ke telapak tangan kemudian menggosok perlahan. Hal tersebut dilakukan hingga warga memahami sehingga dapat melakukan sosialisasi ke lingkungan keluarga masing-masing. Serta dilakukan sosialisasi usaha yang wajib dilakukan dengan disiplin saat ini seperti menjaga jarak 1 meter dengan orang lain, hindari berkumpul dengan banyak orang, jangan menyentuh wajah, mulut, hidung dan mata, lakukan cuci tangan sebelum masuk ke rumah dan makan, selalu menggunakan masker sesuai standar WHO.

Evaluasi terhadap pelaksanaan kegiatan ini dengan memberikan kuesioner yang berisi pengetahuan mitra tentang perilaku hidup bersih dan sehat, cara cuci tangan yang benar, dan penggunaan masker yang benar serta pendapat tentang program ini bermanfaat atau tidak dan untuk program selanjutnya apakah yang diinginkan dari mitra. Berdasarkan hasil sebelum dan sesudah penyuluhan didapatkan bahwa terjadi peningkatan pengetahuan dari $18,18 \%$ menjadi $98,18 \%$ yang dapat dilihat pada tabel 1 dan 3 .

Tabel 3. Distribusi Pengetahuan Responden Setelah Penyuluhan

\begin{tabular}{|c|c|c|}
\hline Pengetahuan & Frekuensi (F) & Presentase (\%) \\
\hline Baik & 54 & 98,18 \\
\hline Kurang & 1 & 1,82 \\
\hline Jumlah & 55 & 100 \\
\hline
\end{tabular}

Pengetahuan warga meningkat signifikan sehingga warga diharapkan dapat meningkatkan pengetahuan, kesadaran, dan kemampuan masyarakat untuk melakukan PHBS dalam meningkatkan mutu hidup serta meningkatkan taraf kesehatan masyarakat untuk mencegah berbagai penyakit [10] [11] [12].

\section{KESIMPULAN}


Warga RT 01 RW 02 Jatisari Jatiasih Bekasi dapat memperoleh pengetahuan baru mengenai PHBS, cara menggunakan masker yang benar sesuai standar WHO, serta cara mencuci tangan yang benar untuk meningkatkan taraf derajat kesehatan masyarakat. Upaya ini harus terus dilakukan secara disiplin untuk mewujudkan kesehatan masyarakat setinggitingginya.

\section{SARAN}

Berbagai upaya lain juga perlu terus dilakukan untuk menjaga kesehatan di masa pandemi seperti ini, mengingat wabah covid ini selain kesehatan juga akan memberikan dampak serius bagi ekonomi warga. Maka perlu pengabdian masyarakat mengenai upaya untuk menjaga stabilitas ekonomi warga yang terdampak wabah ini.

\section{UCAPAN TERIMA KASIH}

Penulis mengucapkan terima kasih kepada LPPM Universitas Muhammadiyah Prof.DR.HAMKA yang telah memberi dukungan financial terhadap pengabdian masyarakat ini.

\section{DAFTAR PUSTAKA}

[1] World Health Organization, WHOAnjuran mengenai penggunaan masker dalam konteks COVID-19., 2020, Anjuran Mengenai Penggunaan Masker Dalam Konteks COVID-19. World Health Organization (April):1-17.

[2] Gani, Husni Abdul, Erdi Istiaji, and Prita Eka Pratiwi., 2015, Perilaku Hidup Bersih Dan Sehat (PHBS) Pada Tatanan Rumah Tangga Masyarakat Using (Studi Kualitatif Di Desa Kemiren, Kecamatan Glagah, Kabupaten Banyuwangi) A Qualitative Study in Kemiren Village, Glagah Sub District, Banyuwangi Regency, Jurnal IKESMA, 11(1):26-35.

[3] Andriansyah, Yuli, and Desi Natalia Rahmantari., 2013, Penyuluhan Dan Praktik Phbs ( Perilaku Hidup Bersih, Inovasi Dan Kewirausahaan, 2(1):45-50.

[4] Bekti, Rokhana Dwi, Kris Suryowati, and Hadi Prasetyo Suseno., 2020, Pemberian Sosialisasi Dan Bantuan Pencegahan Covid-19 Bagi Warga Malangan Kota Yogyakarta Berdasarkan Analisis Tingkat Pengetahuan, Abdimasku: Jurnal Pengabdian Masyarakat, 3(3):99.

[5] Wei, Wycliffe E., Zongbin Li, Calvin J. Chiew, Sarah E. Yong, Matthias P. Toh, and Vernon J. Lee., 2020, Presymptomatic Transmission of SARS-CoV-2-Singapore, Morbidity and Mortality Weekly Report, 69(14):411-15.

[6] Utomo, Agung Prasetyo, Widya Emilia Primaningtyas, Mahasin Maulana Ahmad, Imah Luluk Kusminah, Rocky Andiana, Ayu Nindyapuspa, Sri Tjahyonowatie, and Dwi Setia Ningrum., 2020, Pelatihan Pembuatan Hand Sanitizer Dan Aplikasi Pola Hidup Bersih Di SMK Negeri 4 Surabaya Dalam Upaya Menyikapi Pandemi COVID-19, Educivilia: Jurnal Pengabdian Pada Masyarakat, 1(2):111. 
[7] Firdausi, Umni, Listania Felia Kartika Candra, and Carolus Prima Ferri Karma, 2020, Pengabdian Masyarakat Dan Anak - Anak Melalui Kkn-T Mengenai Edukasi Pencegahan Covid-19 Di Desa Dukuh Cikupa, ABDIPRAJA (Jurnal Pengabdian Kepada Masyarakat), $1(1): 14$.

[8] Hartati, Puji., Susanto., 2020, Peran Pemuda Tani Dalam Pencegahan Penyebaran Covid-19 Di Tingkat Petani (Kasus Di Kabupaten Magelang), Journal of Business \& Entrepreneurship, 2(2):107-12.

[9] Devi Pramita Sari, and Nabila Sholihah 'Atiqoh., 2020, Hubungan Antara Pengetahuan Masyarakat Dengan Kepatuhan Penggunaan Masker Sebagai Upaya Pencegahan Penyakit Covid-19 Di Ngronggah, Infokes: Jurnal Ilmiah Rekam Medis Dan Informatika Kesehatan 10(1):52-55.

[10] Ausrianti, Rizka, Rifka Putri Andayani, Defrima Oka Surya, and Ulfa Suryani., 2020., Edukasi Pencegahan Penularan Covid 19 Serta Dukungan Kesehatan Jiwa Dan Psikososial Pada Pengemudi Ojek Online, Jurnal Peduli Masyarakat, 2(2):59-64.

[11] Ayu Kurniawati, Kiki Riska, Farah Heniati Santosa, and Samsul Bahri., 2020, Sosialisasi Hidup Sehat Di Tengah Wabah Virus Corona, JPMB : Jurnal Pemberdayaan Masyarakat Berkarakter, 3(1):58-65.

[12] Andriansyah, Yuli, and Desi Natalia Rahmantari., 2013, "Penyuluhan Dan Praktik Phbs ( Perilaku Hidup Bersih.” Inovasi Dan Kewirausahaan 2(1):45-50. 